
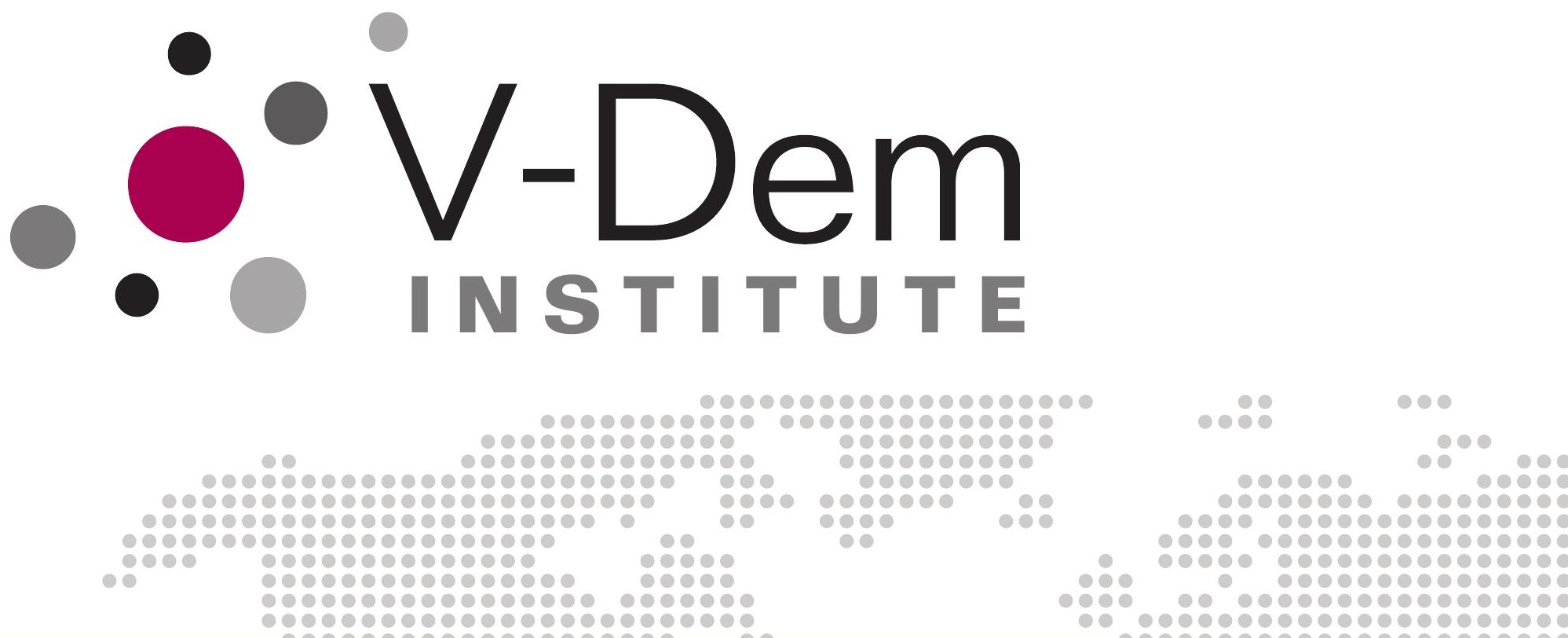

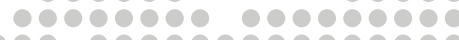

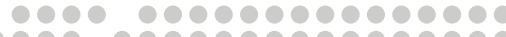

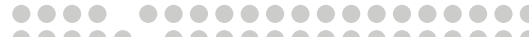

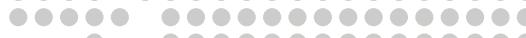

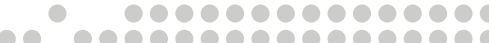

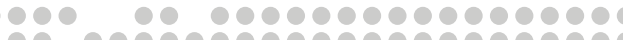
00000000000000000000000

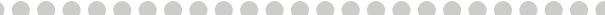

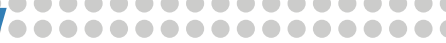

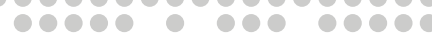

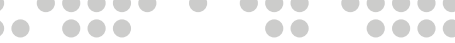

Sequential Requisites Analysis: A New Method for Analyzing Sequential Relationships in Ordinal Data

Patrik Lindenfors, Joshua Krusell, Staffan I. Lindberg

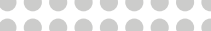

0009000

1000000

090000

10000

1000

000

10

10

O

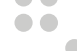

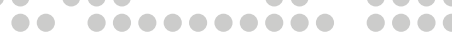

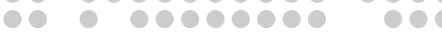

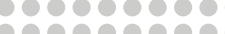

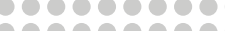

10000000000000

1000000000000000000

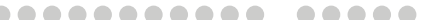

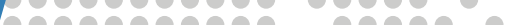

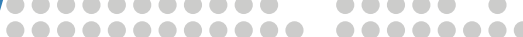

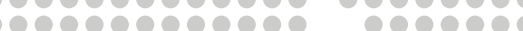

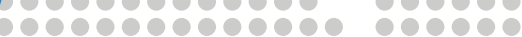

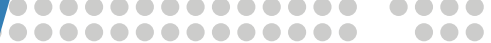

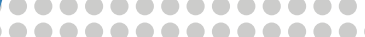

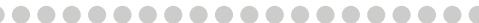

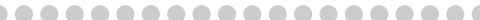
0000000000000009

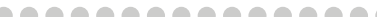

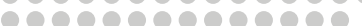

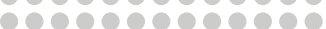

190909090900

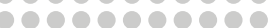

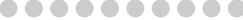

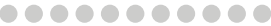

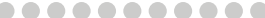

90000000000

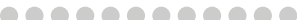

-

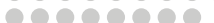

(0000000

0000000

○००0000

00000

1000

200

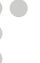


Varieties of Democracy (V-Dem) is a new approach to the conceptualization and measurement of democracy. It is co-hosted by the University of Gothenburg and University of Notre Dame. With a V-Dem Institute at University of Gothenburg that comprises almost ten staff members, and a project team across the world with four Principal Investigators, fifteen Project Managers, 30+ Regional Managers, 170 Country Coordinators, Research Assistants, and 2,500 Country Experts, the V-Dem project is one of the largest-ever social science researchoriented data collection programs.

Please address comments and/or queries for information to:

V-Dem Institute

Department of Political Science

University of Gothenburg

Sprängkullsgatan 19, PO Box 711

SE 40530 Gothenburg

Sweden

E-mail: contact@v-dem.net

V-Dem Working Papers are available in electronic format at www.v-dem.net.

Copyright (C) 2016 by authors. All rights reserved. 


\title{
Sequential Requisites Analysis: A New Method for Analyzing Sequential Relationships in Ordinal Data ${ }^{*}$
}

\author{
Patrik Lindenfors \\ Associate Professor of Zoological Ecology \\ Centre for the Study of Cultural Evolution \& Department of Zoology \\ Stockholm University \\ Joshua Krusell \\ Data Manager, V-Dem Institute \\ University of Gothenburg \\ Staffan I. Lindberg \\ Professor of Political Science \\ Director, V-Dem Institute \\ University of Gothenburg
}

\footnotetext{
- This research project was supported by Riksbankens Jubileumsfond, Grant M13-0559:1, PI: Staffan I. Lindberg, V-Dem Institute, University of Gothenburg, Sweden; by Swedish Research Council, Grant C0556201, PIs: Staffan I. Lindberg, V-Dem Institute, University of Gothenburg, Sweden and Jan Teorell, Department of Political Science, Lund University, Sweden; by Knut and Alice Wallenberg Foundation to Wallenberg Academy Fellow Staffan I. Lindberg, Grant 2013.0166, V-Dem Institute, University of Gothenburg, Sweden; as well as by internal grants from the Vice-Chancellor's office, the Dean of the College of Social Sciences, and the Department of Political Science at University of Gothenburg. We performed simulations and other computational tasks using resources provided by the Notre Dame Center for Research Computing (CRC) through the High Performance Computing section and the Swedish National Infrastructure for Computing (SNIC) at the National Supercomputer Centre in Sweden. We specifically acknowledge the assistance of In-Saeng Suh at CRC and Johan Raber at SNIC in facilitating our use of their respective systems.
} 


\begin{abstract}
This paper presents a new method inspired by evolutionary biology for analyzing longer sequences of requisites for the emergence of particular outcome variables across numerous combinations of ordinal variables in social science analysis. The approach involves repeated pairwise investigations of states in a set of variables and identifying what states in the variables that occur before states in all other variables. We illustrate the proposed method by analyzing a set of variables from version 6 of the V-Dem dataset (Coppedge et al. 2015a, b). With a large set of indicators measured over many years, the method makes it possible to explore long, complex sequences across many variables in quantitative datasets. This affords an opportunity, for example, to disentangle the sequential requisites of failing and successful sequences in democratization. For policy purposes this is instrumental: Which components of democracy are most exogenous and least endogenous and therefore the ideal targets for democracy promotion at different stages?
\end{abstract}




\section{Introduction}

Sequences are critical to understanding many social processes such as regime transitions, onset of civil wars, economic development, and institutional development. The subject of specific concern to us that has important policy-implications is the study of democratization. This is a field of study endowed with persuasive theorists and accomplished area experts (e.g. Dahl 1971, Diamond et al 1988, Linz et al 1996, O’Donnell et al 1986, Schedler 2013). They provide us with abundant lessons from both detailed country case-studies and comparative analyses. Large-N datasets on democracy and democratization emerged already in the 1960s with the purpose of evaluating more general hypotheses. The field has since seen substantial increasing methodological sophistication (e.g. Acemoglu et al. 2001, Bollen 1993, Inglehart et al 2005, Jackman 1973, Norris 2008, Lipset 1959, Przeworski et al 2000), but has also become crowded with typologies depicting various semi-authoritarian regimes (e.g. Gandhi et al 2007; Geddes 1999; Levitsky et al 2002), democratic regimes (e.g., Lijphart 1999), innumerable subtypes (Collier et al 1997), and full typologies from autocratic to democratic regimes (e.g. Diamond 2002).

A core issue remains, however. Existing studies habitually provide evidence on variables related to democratization (e.g. Acemoglu et al 2005, Boix 2003, Coppedge 2012, Przeworski 1991, Teorell 2010) from which causal inferences are attempted. Yet, we have been unable to use large- $\mathrm{N}$ data to depict the series of requisite conditions that are typical for countries making their way from one regime to another. We "know" that processes of democratization are messy with many factors interacting over time that eventually produce either good or less good outcomes. However, we have been unable to both measure all those aspects systematically across the world and along extended time spans, and even less able to systematically analyze the many sequential and interrelated changes among those variables. The Varieties of Democracy (V-Dem) dataset has solved the first issue providing data on over 350 variables across 173 countries and the period from 1900 to 2012 (Coppedge et al. 2015a, b). A first effort at solving the second issue was presented in Lindenfors et al. (2015). The present paper takes that framework significantly further and presents what we believe to be a viable solution to the second problem. 


\section{On the State of the Field of Democratization}

One subset of scholars have focused on which variables external to the political system that may increase the probability of democratization, such as geography, modernization, colonialism, inequality, and societal/class conflict. Lipset's milestone (1959) sparked a long deliberation on whether, or to what extent, economic development, or more broadly modernization, affects democratization and democratic consolidation (Acemoglu et al 2009; Bollen 1983; Burkhart et al 1994; Huntington 1991; Knutsen et al 2015; Przeworski et al 1997). Yet, the field seems not to have produced a definitive answer to the question if economic development is beneficial for democratic stability but not transitions (Przeworski et al. 2000); if it facilitates neither transitions nor stability (Acemoglu et al. 2009); or that it furthers both of them (Boix 2003).

Another group focuses on research on endogenous dynamics of democratization. These are studies analyzing how parts of what we think of as a democratic regime, or autocracy, affect each other in positive or negative ways. Much of the early writing took "big" approaches to democratizations. For example, Rustow's (1970) timeless piece suggested four inter-related stages of democratization: national unity, prolonged political struggle, deliberate accords, and habituation to democratic rules (c.f. Carothers 2002). O’Donnell et al (1986) finds that democratization is more likely when a bargaining between moderate actors ("soft-liners") on both sides precedes a "founding" election and projected four transition processes with varying outcomes. Linz et al (1996: 57-60) argue instead that there are six alternative pathways of democratic transitions, each with different consequences for democratic consolidation (see also Karl 1990; Munck et al 1997.)

More recently, many scholars have taken a more disaggregated approach and looking at specific aspects rather than entire processes of democratization, thus identifying something narrower than "democracy" as their dependent variable. These works are typically associated with more restricted claims, like if individual rights and institutional checks and balances go before mass suffrage, democracy has a higher probability of enduring (Berlin 2002), or that repeated elections - even if not entirely free and fair - are instrumental to spur and sustain processes of expanding civil liberties (Howard et al 2006; Lindberg (2006). Again, we find contradictory results such that elections can be a constituent and stabilizing component of dictatorship (e.g. Gandhi et al 2007). The literature on the role of civil society has produced more coherent results generally viewing the mobilization of civil society as critical to the breakdown of authoritarianism and good for democratic consolidation (Bernhard 1993; Bunce 2010; Ekiert et al 1999; O’Donnell et al 1986; Putnam 1993), even if it has also been argued that a civil society conveying the interests of society to the regime may promote authoritarian 
stability (Gandhi 2010, Magaloni 2008). The role of political parties suggests that where parties are poorly institutionalized electoral regimes are likely to lack stability (Bernhard et al 2015; Hicken et al 2011; Roberts et al 1999).

Thus, a great deal of work in political science seeks to investigate the order of events or utilizes historical process tracing of complex sequential relationships to explain political outcomes such as democratization. The sequences of complex social processes usually involve hundreds of related variables with a large number of characteristics, and today's standard techniques for time-series, cross-sectional (TSCS) analysis for observational panel-data, are not very apt for this sort of problems. First, they do not solve the causal inference problem to a greater or lesser degree than the approach suggested here below. Second, they typically force analysts to make very strong assumptions about invariant time-distance between $x$ and $y$ in terms of which lag should be used. Third, they are designed for giving insights into the average effect of $x_{i}$ on $y$ given the conditions $z_{i}$, sometimes taking interaction effects into account. However, the social and political processes that we as social scientists are typically interested in, such as democratization, are rarely even approximations of such simplifications. Rather, complex and often long series of sequentially related variables are in play and contribute to the outcome.

Finally, large-N research on sequences in political science has been hampered by the lack of appropriate data. The quality, conceptual validity, and reliability of the extant sources on democracy are discussed by others (e.g. Coppedge et al. 2015). For sequential analysis of democratization, one needs long time series covering as many countries as possible. This makes sources like BNR index (Bernhard et al. 2001), Bertelsmann Transformation Index (Bertelsmann Foundation), the European Intelligence Unit's index (EIU 2010), the Democracy Barometer (Bühlmann et 1. 2012), and the World Governance Indicators (Kaufmann 2010) less useful. The remaining sources all suffer from being highly aggregated and lacking detailed measures of individual aspects of democracy that can be used for sequential analysis, including Freedom House's political rights and civil liberties ratings (freedomhouse.org), Polity IV's democracy and autocracy scores and their components (Marshall et al. 2014), the Unified Democracy Scores (Pemstein et al. 2010), the democracy-dictatorship index (Alvarez et al. 1996; Cheibub et al. 2010), the Lexical index of electoral democracy (Skaaning et al. 2015), the Competition and Participation indices developed by Tatu Vanhanen (2000), the BMR index (Boix et al. 2013), and the Contestation and Inclusiveness indices (Coppedge et al. 2008). In effect, researchers have only had highly aggregated indices of democracy to draw upon, and since there have been no appropriate methods developed for analysis of time-variant, sequential 
relationships across many variables, it has never been possible to test propositions about more specific relationships in a systematic and comprehensive fashion.

\section{Sequence Analysis of Ordinal Data Customized from Evolutionary Biology}

We suggest here a new method - the sequential requisites analysis - to enable delineation and testing of long series of requisites involving many variables, while capitalizing on V-Dem's multidimensional understanding of democracy and provision of over 350 highly disaggregated measures of various aspects of democracy for 173 countries from 1900 to 2012. This combination of the new data and a new method inspired by evolutionary biology offers an opportunity to evaluate existing theories of failing and successful sequences of democratization in the most rigorous fashion possible taking full advantage of the complete universe of available data. Perhaps even more significant, unexplored and under-theorized chains of sequential requisites can be investigated with this method. The method we describe here makes it possible to search for sequences not necessarily contemplated by current theory - and do so with regards to long chains of sequential relationships between many factors.

This is a form of descriptive, basic research whose importance should not be underestimated. Description has led to groundbreaking advances across many sciences, including evolutionary biology from which we adapt methodological approaches. Simply put, we do not know the answers yet to relatively simple questions like: When a country transitions from autocracy to democracy (or vice versa), which elements come first? Which are the common patterns, a finite set of sequences for sequences that are failing to lead to democracy, and those that result in democratization?

With a large set of indicators measured over many years, it would become possible for the first time to explore transition sequences. ${ }^{1}$ It is quite possible, maybe even probable, that there are varying paths - sequences of conditional relationships - to each of them. This affords an opportunity to disentangle the sequential requisites of failing and successful sequences in democratization. For policy purposes this is also instrumental: Which components of democracy are most exogenous (affecting other components) and least endogenous (dependent

\footnotetext{
${ }^{1}$ Sequencing is explored by Schneider et al (2004) and Wilson $(2014,2015)$ with a smaller set of indicators and/or a shorter stretch of time. See also McFaul (2005) and Møller et al (2010).
} 
on other components) and therefore the ideal targets for democracy promotion at different stages?

Elsewhere, we have suggested a set of methods to identify sequences within a set of variables (Lindenfors et al. 2015). There exist a number of approaches to identify sequences in ordinal and categorical time series data, many more or less inspired by evolutionary biology. Noteworthy are e.g. social sequence analyses that are inspired by DNA sequence analyses (e.g. Abbott 1995; Abbot \& Tsay 2000, Gauthier et al. 2010, Casper and Wilson 2015), set theoretic approaches such as qualitative comparative analysis (QCA) (Ragin 1987; Rihoux \& Ragin 2009), and time-series cross-section methods (Beck 2008). There also exists a more novel approach using Bayesian modelling to construe dynamic systems indicating flow of change (Ranganathan et al. 2014; Spaiser et al. 2014). As mentioned before, we have also suggested a number of methods, graphical and analytical (Lindenfors et al. 2015). All these methods have their pros and cons, where method choice is dependent on the format of the data and the specific question of interest. The method presented here sits comfortably in the set-theoretic tradition (see e.g. Paine 2016; Thiem et al. 2016; Schneider 2016 for discussions on these methods), though we would like to shy away from inferring causation and instead focus on the method's ability to describe historical pathways.

Analyses based on the approach proposed below can in principle be conducted for qualitative data measured at any level (interval, ordinal, binary) but in practice, it requires ordinal or binary variables in order to be easily interpretable. The analysis is also easier to interpret if all variables in a particular analysis have the same level of measurement, but this is not required.

From the analysis, combining a series of bivariate analyses (by running all variables against all), one can establish long series of sequences involving many multi-state variables. The result is a detailed and empirically based "map" of which aspects of a phenomenon that tends to occur before other aspects. In other words, we are now capable of providing the first solution to presenting detailed sequences of democratization and other similar phenomena. Also, the requisite analysis presented below promises us to be in a much better position to answer prescriptive questions with a strong empirical foundation.

Here we present an extended requisite analysis to identify historically realized sequences of events between states of variables. We suggest that the approach detailed below can establish descriptive sequences in terms of conditions among, in principle, an unlimited number of multistate ordinal variables over any stretch of time, given that adequate data is available and that there are, in fact, sequential relationships to be found. To the extent that one can establish that any one sequence across time and space always, or almost always, precedes the outcome, we 
have arguably come a long way in terms of arriving at a general understanding of and explanation to such a social process compared to where we are today. Until now, we have not been able to provide evidence of such sequences at all across time and a large number of units, other than by individual case analysis found for example in historical sociology and in-depth case-study approaches.

\section{Data}

To explore the temporal relationship between various aspects of democracy utilizing the proposed sequence analysis approach, we use the V-Dem dataset v6 for the purposes of presenting. V-Dem aims to achieve transparency, precision, and realistic estimates of uncertainty with respect to each data point. The v6 dataset includes 173 sovereign or semi-sovereign states from 1900 to 2012, and data covering 2013-2014 for 60 of these countries. ${ }^{2}$

The indicators in the "V-Dem Codebook" fall into three main categories: 1) factual data gathered from other datasets or original sources; 2) evaluative indicators coded by multiple country experts; and 3) aggregated indices constructed by combining several indicators that load on the same dimension based on factor analysis results. The evaluative indicators are produced according to a complex and demanding protocol. Typically, five or more independent country experts code each country-year for each indicator and almost three thousand experts have been involved in the coding to date. ${ }^{3}$ To arrive at the best possible estimates, V-Dem has a team of measurement experts and methodologists who have developed an advanced Bayesian ordinal IRT-model for aggregating and weighting expert ratings and for calculating confidence intervals alongside a series of validity and reliability tests, including tests of intercoder reliability (see Pemstein et al 2015 and Coppedge et al 2015c). This model takes into account the possibilities that experts may make mistakes and have different scales in mind when providing judgments ${ }^{4}$. Indicators in V-Dem are mostly on an ordinal scale from 0 to 4 (originally, the dataset also

\footnotetext{
${ }^{2}$ A detailed explanation of the V-Dem approach can be found on V-Dem's website, https://v-dem.net, along with the other V-Dem documents cited in this paper.

${ }^{3}$ The coders' considerable knowledge derives from a combination of experience and education: Most have lived in their countries of expertise for nearly thirty years, and 60 percent are nationals of that country. In addition, 90 percent have postgraduate degrees. Ratings accorded to a country are therefore largely the product of in-country expert judgments. In addition to providing a rating on each indicator, country experts also assign a "confidence score" (0 to 100), which measures how certain we can be about the rating. In addition, roughly a fifth of the coders undertake cross-country coding, making it possible for us to calibrate measurements between countries.

${ }^{4}$ Simulations and other computational tasks to produce the V-Dem dataset was done using resources provided by the Notre Dame Center for Research Computing (CRC) through the High Performance Computing section and the Swedish National Infrastructure for Computing (SNIC) at the National Supercomputer Centre in Sweden. We specifically acknowledge the assistance of In-Saeng Suh at CRC and Johan Raber at SNIC in facilitating our use of their respective systems.
} 
provides other versions). For indices where the original V-Dem scale runs from 0 to 1 has been transformed to ordinal categories ranging from 0 to 4, created and validated by Lindberg (2015) in order to enable the sequence analysis we are aiming for here. Note, however, that the analysis does not require an equal number of steps in the ordinal values utilized, although it does make interpretation easier. If there are an unequal number of steps, then variables can be standardized, or results interpreted 'as is'.

\section{The New Method: Sequential Requisites' Analysis}

To explore whether certain states of one variable are systematically conditional on certain states of other variables in existing data, we here extended the method termed 'dependency analysis' from an earlier paper (Lindenfors et al. 2015). The method is inspired primarily by "the contingent states test," which is an established method developed to investigate historical sequences in biological evolution (Sillén-Tullberg 1993), with reasoning particularly well suited to use on sequence data outside biology. It also has some similarities with qualitative comparative analysis (QCA) (Ragin 1987; Rihoux \& Ragin 2009) - indeed, in some sense it can be viewed as a modification thereof. Note that even though variables may co-vary the proposed method checks for requisites in the data, not statistical correlations. This is an important distinction since if and when one can establish such requisites - assuming that the data is more or less complete in coverage - this is evidence actual historical sequences realized in the data.

To conduct this type of dependency analyses, for each state of one variable, scan the dataset for the lowest state in all other variables. If higher states in one variable always correspond to higher "lowest states" in the other variables, then it can be inferred that certain states of that variable are likely to have been be conditional on certain states of the other variables. If, on the other hand, for each state of the variable, the corresponding "lowest state" in the other variables are at their minimum, then this shows that change in the focal variable is not restricted by the other variables. These observations in combination indicate that potential dependencies between the variables exist only in one direction. Requisite should not be taken here as a causal relation, but as a description of historical observations: certain values for a certain focal variable have been conditional on certain values for the others. To allow some margin of error, a percentile of observations can be specified and treated as the "lowest values," which will slightly relax the criterion of absolute dependencies. We here report dependencies allowing such a 95\% "wiggle room," following the convention in QCA.

Table 1 shows an example of the described procedure. The table indicates that the highest state of some variables occur only together with higher values in the others. This means, for 
example, that "Legislature investigates in practice" only exists in its highest state if "Health Equality" is at least 2, "Election free and fair" is at least 4, and all the others are at least 3. On the other hand, the "Elected executive index" occurs in its highest state regardless of the values of the others, with the exception that "Access to justice for women" is at least 1 . The sums listed in the right column indicates the sums of requisites from the highest to lowest. The sums listed in the bottom row indicates the sum of states that the other variables are dependent on. Thus, the order bottom to top indicate a sequence where the top variables are more dependent on reformed states of the bottom variables. Likewise, the order left to right indicate a sequence of dependencies where variables are more contingent on reformed states of the rightmost variables. The two lists, row and column, will be similar by necessity, but need not be identical. Note that the row and column sums need not depend on dependencies of the same variables, so some care has to be taken in interpreting these sums when comparing variables - variables can be compared, if that is deemed desirable, is through the use of Euclidean distance between requisite rows. Note also that the method is descriptive rather than hypothesis testing, so no significance values are reported. 


\section{Table 1:}

Example of dependency table for the highest state of each variable. The highest state of the variables listed in the left column have not occurred in the data if the state indicated by the numbers in the table were not reached for each variable listed in the top row. For example, the variable "Legislature investigates in practice" has only been observed to exist in its highest state if "Health Equality" was at least 2, "Election free and fair" at least 4, and all the others at least 3 .

Legislature investigates in practice

Access to justice for women

High court independence

Harassment of journalists

CSO entry and exit

Election free and fair

Executive bribery and corrupt exchanges

Health equality

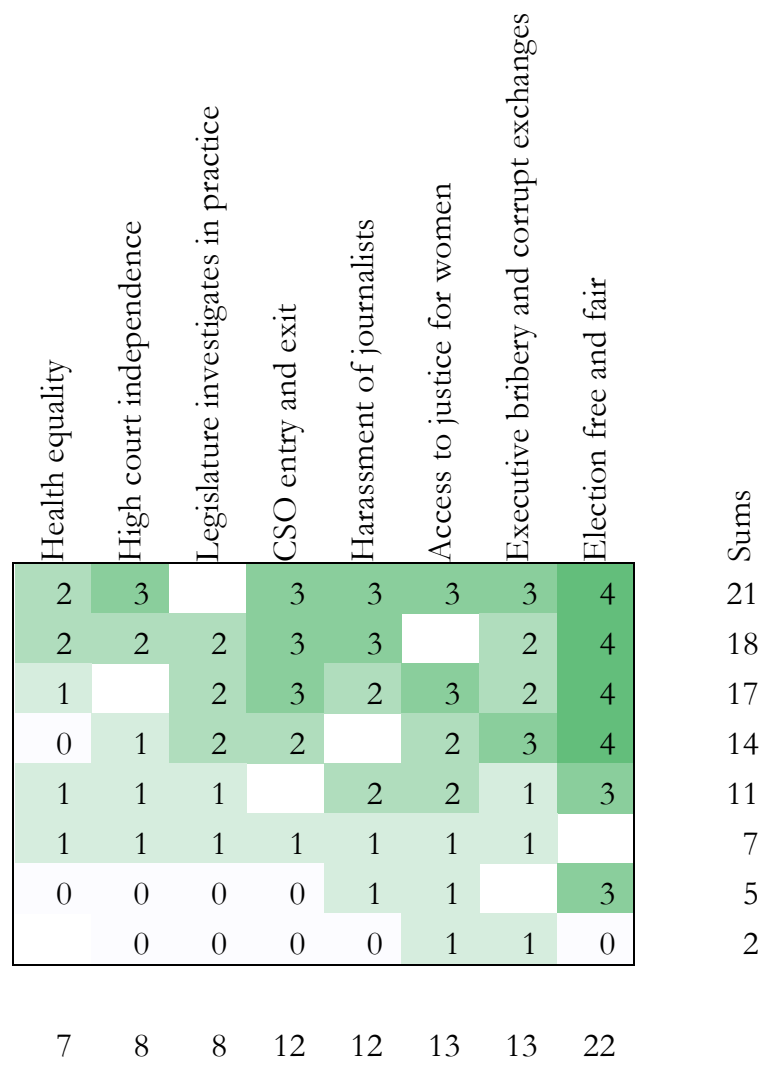

Sums

From Table 1, it may seem that improvements in the rightmost variables are necessary conditions for improvements in the top variables. However, as the observed relationship is historical rather that causal, one should be careful implying a direct causal relationship (see e.g. Paine 2016; Thiem et al. 2016; Schneider 2016). A low number of dependencies for all states of a variable, though, indicates that there are very few necessary conditions for it to assume higher states - this can be stated firmly. However, the converse claim of causality is less supported. If a variable has a high number of requisites, this indicates that it historically never has reached higher states before a number of other variables have reached high levels, but any causal claim has to be made very carefully. 


\section{Table 2:}

Example of dependency table for the all states of each variable. The state indicated of the variables listed in the left column have not occurred if the states indicated by the numbers in the table were not reached for each variable listed in the top row. For example, state 3 of the variable "Harassment of journalists" has only been observed to exist if "Election free and fair" was at least 2 and all other variables at least 1.

Legislature investigates in practice 4

Access to justice for women 4

High court independence 4

Harassment of journalists 4

CSO entry and exit 4

Harassment of journalists 3

Election free and fair 4

Legislature investigates in practice 3

Executive bribery and corrupt exchanges 4

CSO entry and exit 3

Access to justice for women 3

High court independence 3

Harassment of journalists 2

Election free and fair 3

Election free and fair 2

Legislature investigates in practice 2

Health equality 4

CSO entry and exit 2

Legislature investigates in practice 1

Health equality 3

Health equality 2

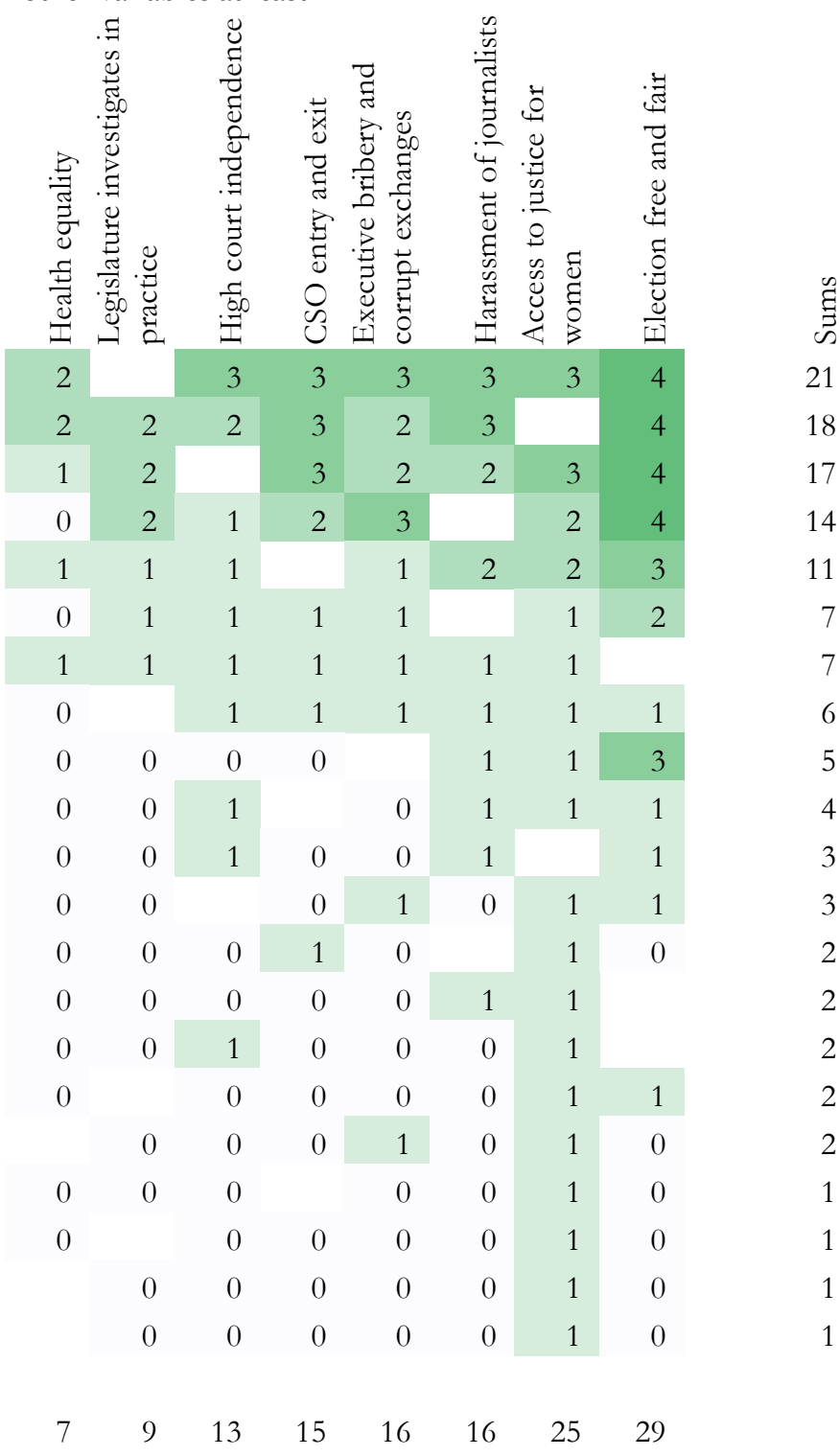

Harassment of journalists 1

CSO entry and exit 1

Election free and fair 1

Access to justice for women 1-2

High court independence 1-2

Health equality 1

Executive bribery and corrupt exchanges 1-3

$\begin{array}{lllllllll}0 & 0 & 0 & 0 & 0 & & 0 & 0 & 0 \\ 0 & 0 & 0 & & 0 & 0 & 0 & 0 & 0 \\ 0 & 0 & 0 & 0 & 0 & 0 & 0 & & 0 \\ 0 & 0 & 0 & 0 & 0 & 0 & & 0 & 0 \\ 0 & 0 & & 0 & 0 & 0 & 0 & 0 & 0 \\ & 0 & 0 & 0 & 0 & 0 & 0 & 0 & 0 \\ 0 & 0 & 0 & 0 & & 0 & 0 & 0 & 0\end{array}$

For an analysis of sequential relationships between a larger number of states in all variables, a dependency table can be constructed for all possible combinations of states of the variables, and summarized. We here present a larger table indicating the order of all states in the 
variables (Table 2). Thus, we can get a good sense of which variables come first, middle, and last in processes. This example of looking at the state-dependencies is of particular interest when one is analyzing for example what conditional relationships look like for achieving democratization.

The proposed method can be made to fail through analyzing variables with very skewed distributions, for example if all observed states for one variable are in the same state, or very few exceptions exist. Misleading results can also be the product of analyses where there are very few observations in total.

\section{Conclussions}

This paper details a new approach to the study of sequences in ordinal data in social science: requisite tables. The usefulness of this analytic tool is illustrated with a simple sequence analysis of eight ordinal values from the V-Dem electoral Democracy index (as per the v6 of the V-Dem dataset). We believe this approach has great potential for the analysis of many types of pressing issues that social science confronts, not the least the sequences of democratization. We hope to use this method in the near future to be able to answer critical questions of successful and unsuccessful sequences, as well as what democracy support should focus on at various stages of democratization in ways that can directly inform policy and practitioners' priorities. 


\section{References}

Abbott, A. (1995). "Sequence Analysis: New Methods for Old Ideas." Annual Review of Sociology, 21: 93-113.

Abbott, A., \& Tsay, A. (2000). "Sequence analysis and optimal matching methods in sociology review and prospect”. Sociological Methods \& Research, 29(1), 3-33.

Acemoglu, D., Johnson, S., Robinson, J. A., \& Yared, P. (2009). "Reevaluating the Modernization Hypothesis.” Journal of Monetary Economics 56(8): 1043-1058.

Acemoglu, D., \& Robinson, J. A. (2001. "A Theory of Political Transitions.” American Economic Review 91(4): 938-963.

Alvarez, M., Cheibub, J. A., Limongi, F., \& Przeworski A. (1996). "Classifying Political Regimes." Studies in Comparative International Development 31(2): 3-36.

Beck, N. (2008). Time-Series-Cross-Section Methods. Oxford Handbook of Political Methodology, 475-93.

Berlin, I. (2002). Liberty. Oxford: Oxford University Press.

Bernhard, M. (1993). "Civil Society and Democratic Transition in East Central Europe" Political Science Quarterly, 108(2): 307-326.

Bernhard, M., Hicken A., Reenock, C., \& Lindberg, S. I. (2015). "Institutional Subsystems and the Survival of Democracy: Do Political and Civil Society Matter?" Varieties of Democracy Institute: Working Paper Series, No. 4.

Bernhard, M., Nordstrom, T., \& Reenock, C. (2001). "Economic Performance, Institutional Intermediation, and Democratic Survival." Journal of Politics 63(3): 775-803.

Bertelsmann Stiftung. [various years]. Bertelsmann Transformation Index [2003-]: Towards Democracy and a Market Economy. Washington, DC: Brookings Institution Press.

Boix, C., Miller, M., Rosato, S. (2013). “A Complete Dataset of Political Regimes, 1800-2007.” Comparative Political Studies 46(12), 1523-1554.

Boix, C. (2003). Democracy and Redistribution. New York: Cambridge University Press.

Bollen, K. A. 1983. "World System Position, Dependency and Political Democracy." American Sociological Review 48:468-79.

Bollen, K. A. (1993). "Liberal Democracy: Validity and Method Factors in Cross-National Measures." American Journal of Political Science 37(4): 1207-1230.

Bühlmann, M., Merkel, W., Müller, L., \& Weßels, B. (2012). “The Democracy Barometer: A New Instrument to Measure the Quality of Democracy and Its Potential for Comparative Research.” European Political Science 11(4): 519-536. 
Bunce, V. (2010). Defeating Authoritarian Leaders in Postcommunist Countries. Cambridge: Cambridge University Press.

Burkhart, R. E., \& Lewis-Beck, M. S. (1994). Comparative democracy: the economic development thesis. American Political Science Review, 88(4): 903-910.

Carothers, T. (2002). “The End of the Transition Paradigm”. Journal of Democracy 13(1): 5-21.

Casper, G., \& Wilson, M. (2015). "Using Sequences to Model Crises.” Political Science Research and Methods 3(2): 381-97.

Cheibub, J. A., Gandhi, J., \& Vreeland, J. R. (2010). “Democracy and Dictatorship Revisited." Public Choice 143(1-2): 67-101.

Collier, D., \& Levitsky, S. (1997). "Democracy with Adjectives: Conceptual Innovation in Comparative Research.” World Politics 49(3): 430-451.

Coppedge M., Gerring J., Lindberg S. I., Skaaning S.-E., \& Teorell J. (2015). "Varieties of Democracy: Comparisons and Contrasts". Varieties of Democracy (V-Dem) Project.

Coppedge, M (2012). Approaching Democracy. Cambridge: Cambridge University Press.

Coppedge, M., Alvarez, A., Maldonado, C. (2008). "Two Persistent Dimensions of Democracy: Contestation and Inclusiveness." Journal of Politics 70(3): 335-350.

Coppedge, M., Gerring, J., Lindberg S. I., Pemstein, D., Skaaning, S.-E., Teorell, J., Tzelgov, E., Marquardt, K., Wang, Y., Pernes, J., Stepanova, N., Miri, F., Mechkova, V., \& Andersson, F. (2015c). "Varieties of Democracy: Methodology v5." Varieties of Democracy (V-Dem) Project.

Coppedge, M., Gerring, J., Lindberg, S. I., Teorell, J., Altman, D., Bernhard, M., Fish, M. S., Glynn, A., Hicken, A., Knutsen, C. H., McMann, K., Pemstein, D., Skaaning, S.-E., Staton, J., Tzelgov, E., Wang, Y., Zimmerman, B., Marquardt, K., \& Miri, F. (2015a). "Varieties of Democracy: Dataset v5." V arieties of Democracy (V-Dem) Project.

Coppedge, M., Gerring, J., Lindberg, S. I., Teorell, J., Altman, D., Bernhard, M., Fish, M. S., Glynn, A., Hicken, A., Knutsen, C. H., McMann, K., Pemstein, D., Skaaning, S.-E., Staton, J., Mechkova, V., \& Andersson, F. (2015b). "Varieties of Democracy: Codebook v5." Varieties of Democracy ( $V$-Dem) Project.

Dahl, R.A. (1971). Polyarchy. Yale University Press.

Diamond, L. (2002). "Elections without Democracy: Thinking about Hybrid Regimes.” Journal of Democracy 13 (2): 21-35.

Diamond, L. J., Linz, J. J., \& Lipset, S. M., eds. (1988). Democracy in Developing Countries. Boulder, CO: Lynne Rienner.

Economist Intelligence Unit (EIU). 2010. Democracy Index 2010: Democracy in Retreat. Economist Intelligence Unit. (http://www.eiu.com/public/democracy_index.aspx), accessed January 25, 
2011.

Ekiert, G., \& Kubik, J. (1999). Rebellious Civil Society. Ann Arbor: University of Michigan Press.

Freedom House. (2015). Methodology. Freedom in the World 2015. New York.

(https://freedomhouse.org/sites/default/files/Methodology_FIW_2015.pdf), accessed December 2, 2015.

Gandhi, J., \& Przeworski, A. (2007). "Authoritarian Institutions and the Survival of Autocrats." Comparative Political Studies 40, no. 11: 1279-1301.

Gandhi, J. (2010). Political Institutions Under Dictatorship. Cambridge: Cambridge University Press.

Gasiorowski, M. J. (1996). “An Overview of the Political Regime Change Dataset.” Comparative Political Studies 29(4): 469-83.

Gauthier, J.-A., Widmer, E. D., Bucher, P., \& Notredame C. (2010). "Multichannel sequence analysis applied to social science data." Sociological Methodology 40(1): 1- 38.

Geddes, B. (1999). What do we know about democratization after twenty years? Annual Review of Political Science, 2(1): 115-144.

Hicken, A., \& Kuhonta, E. M. (2011). "Shadows from the Past: Party System Institutionalization in Asia". Comparative Political Studies 44(5): 572-597.

Howard, M. (2003). The Weakness of Civil Society in Post-Communist Europe. Cambridge: Cambridge University Press.

Howard, M. M., \& Roessler, P. G. (2006). "Liberalizing Electoral Outcomes in Competitive Authoritarian Regimes." American Journal of Political Science 50(2): 365-381.

Huntington, S. P. (1991). The Third Wave: Democratiation in the Late Twentieth Century. Norman, OK: University of Oklahoma Press.

Inglehart, R., \& Welzel, C. (2005). Modernization, Cultural Change and Democracy: The Human Development Sequence. Cambridge: Cambridge University Press.

Jackman, R. W. (1973). "On The Relation of Economic Development to Democratic Performance." American Journal of Political Science 17 (3): 611-621.

Karl, T. L. (1990). "Dilemmas of Democratization in Latin America" Comparative Politics 23(1): 1-21

Kaufmann, D., Kraay, A., \& Mastruzzi, M. (2010). The Worldwide Governance Indicators: Methodology and Analytical Issues. World Bank Policy Research Working Paper No. 5430.

Knutsen, C. H., Gerring, J., Skaaning, S.-E., Teorell, J., Maguire, M., Coppedge, M., \& Lindberg, S. I. (2015). "Economic Development and Democracy: An Electoral Connection". Varieties of Democracy Institute: Working Paper Series, No. 16 
Way, L., \& Levitsky, S. (2002). The rise of competitive authoritarianism. Journal of Democracy, 13(2): 51-65.

Lijphart, A. (1999). Patterns of Democracy: Government Forms and Performance in Thirty-Six Countries. New Haven: Yale University Press.

Lindberg, S. I. (2006). Democracy and Elections in Africa. Baltimore: Johns Hopkins University Press.

Lindberg, S. I. (2015). "Ordinal Versions of the 27 V-Dem Indices: For Classification, Description, Sequencing Analysis and Other Purposes”. University of Gothenburg, Varieties of Democracy Institute: $V$ - Working Paper Series, No. 20.

Lindenfors, P., Jansson, F., Wang, Y., \& Lindberg S. I. (2015). Investigating sequences in ordinal data: A new approach with adapted evolutionary models. Varieties of Democracy Institute: Working Paper No. 18.

Linz, J. J., \& Stepan, A. (1996). Problems of Democratic Transition and Consolidation: Southern Europe, South America, and Post-Communist Europe. Baltimore, MD: Johns Hopkins University Press.

Lipset, S. M. (1959). "Some Social Requisites of Democracy" American Political Science Review 53(1): 69-105.

Magaloni, B. (2008). "Credible Power-Sharing and the Longevity of Authoritarian Rule" Comparative Political Studies 41(4): 715-741.

Marshall, M. G., Gurr, T., \& Jaggers, K. (2014). Polity IV Project: Political Regime Characteristics and Transitions, 1800-2006. (http://home.bi.no/a0110709/PolityIV_manual.pdf), accessed April 9, 2015.

McFaul, M. (2005). “Transitions from Postcommunism.” Journal of Democracy 16(3): 5-19.

Møller, J., \& Skaaning, S.-E. 2010. "Marshall Revisited: The Sequence of Citizenship Rights in the Twenty-First Century.” Government and Opposition 45(4): 457-483.

Munck, G. L., \& Leff C. S. (1997). "Modes of Transition and Democratization: South America and Eastern Europe in Comparative Perspective." Comparative Politics 29(3): 343-362.

Munck, G. L., Verkuilen, J. (2002). “Conceptualizing and Measuring Democracy: Alternative Indices." Comparative Political Studies 35(1): 5-34.

Norris, P. (2008). Driving Democracy. Cambridge: Cambridge University Press

O’Donnell, G., Schmitter, P. C., Arnson, C. J., \& Lowenthal, A. F. (2013). Transitions from authoritarian rule: Tentative conclusions about uncertain democracies. Johns Hopkins University Press.

Paine, J. (2016). "Set-Theoretic Comparative Methods: Less Distinctive Than Claimed." Comparative Political Studies 49: 703-741. 
Pemstein, D., Tzelgov, E., \& Wang, Y. (2015). "Evaluating and Improving Item Response Theory Models for Cross-National Expert Surveys." University of Gothenburg, Varieties of Democracy Institute: V-Dem Working Paper 2015:1.

Pemstein, D., Meserve, S., \& Melton, J. (2010). “Democratic Compromise: A Latent Variable Analysis of Ten Measures of Regime Type.” Political Analysis 18(4): 426-449.

Przeworski, A. (1991). Democracy and the Market. Cambridge: Cambridge University Press.

Przeworski, A., Alvarez, M. E., Cheibub, J. A., \& Limongi, F. (2000). Democracy and Development: Political Institutions and Well-Being in the World, 1950-1990. Cambridge: Cambridge University Press.

Przeworski, A., \& Limongi, F. (1997). "Modernization: Theories and Facts.” World Politics 49(1): 155-183.

Putnam, R. (1993). Making Democracy Work. Princeton University Press.

Ragin, C. C. (1987). The Comparative Method: Moving Beyond Qualitative and Quantitative Strategies. University of California Press.

Ranganathan, S., Spaiser, V., Mann, R. P., \& Sumpter, D. J. (2014). "Bayesian Dynamical Systems Modelling in the Social Sciences". PLoS ONE, 9(1), e86468.

Rihoux, B., \& Ragin, C. C. (Eds.). (2009). Configurational comparative methods: Qualitative comparative analysis (QCA) and related techniques. Sage.

Roberts, K. M., \& Wibbels, E. (1999). Party systems and electoral volatility in Latin America: a test of economic, institutional, and structural explanations. American Political Science Review, 93(03): 575-590.

Rustow, D. (1970). Transitions to Democracy. Comparative Politics, 2: 337-63.

Schedler, A. 2013. The Politics of Uncertainty: Sustaining and Subverting Electoral Authoritarianism. Oxford: Oxford University Press.

Schneider, C. Q., \& Schmitter, P. C. (2004). "Liberalization, Transition and Consolidation: Measuring the Components of Democratization." Democratization 11(5): 59-90.

Sillen-Tullberg, B. (1993). "The effect of biased inclusion of taxa on the correlation between discrete characters in phylogenetic trees." Evolution: 1182-1191.

Skaaning, S.-E., Gerring, J., Bartusevičius, H. (2015). "A Lexical Index of Electoral Democracy." Comparative Political Studies 48(12): 1491-1525.

Spaiser, V., Ranganathan, S., Mann, R. P., \& Sumpter, D. J. (2014). “The Dynamics of Democracy, Development and Cultural Values”. PLoS ONE, 9(6), e97856

Teorell, J. (2010). Determinants of Democratization. Cambridge, Cambridge University Press. 
Thiem, A., Baumgartner M., and Bol, D. 2016. "Still Lost in Translation! A Correction of Three Misunderstandings Between Configurational Comparativists and Regressional Analysts" Comparative Political Studies 49: 742-774.

Vanhanen, T. (2000). “A New Dataset for Measuring Democracy, 1810-1998.” Journal of Peace Research 37(2): 251-265.

Wilson, M. C. (2014). “Governance Built Step-by-Step: Analysing Sequences to Explain Democratization." In Advances in Sequence Analysis: Theory, Method, Applications. eds. Philippe Blanchard, Felix Bühlmann, and Jacques-Antoine Gauthier. New York: Springer International Publishing, 213-27.

Wilson, M. (2015). Castling the King: Institutional Sequencing and Regime Change. Ph.D. Penn State University: Department of Political Science 